\title{
SYNTHESIS, CHARACTERIZATION, AND IN VITRO ANTIMALARIAL ACTIVITY OF DIHYDROXYLATION DERIVATIVES OF TRICLOSAN
}

\author{
WAHYU FITRIANA $^{1}$, ARRY YANUAR ${ }^{1 *}$, ADE ARSIANTI ${ }^{2}$, HIROKI TANIMOTO $^{3}$, KIYOMI KAKIUCHI $^{3}$ \\ ${ }^{1}$ Laboratory of Biomedical Computation and Drug Design, Faculty of Pharmacy, Universitas Indonesia, Depok 16424, Indonesia. \\ ${ }^{2}$ Department of Chemistry, Faculty of Medicine, Universitas Indonesia, Salemba, Jakarta 10430, Indonesia. ${ }^{3}$ Synthetic Organic Chemistry, \\ Graduate School of Materials Sciences, Nara Institute of Science and Technology, Takayamacho, Ikoma, Nara, Japan. \\ Email: arry.yanuar@ui.ac.id
}

Received: 02 October 2019, Revised and Accepted: 24 December 2019

\section{ABSTRACT}

Objective: The emergence of malaria as a global health problem over the past few decades, accompanied by the rise of chemoresistant strains of Plasmodium falciparum, has emphasized the need for the discovery of new therapeutic drugs against this disease. In this study, enantiomerically enriched (enantioenriched) analogs of triclosan were synthesized and evaluated for antimalarial activity against $P$. falciparum cultures.

Methods: Enantioselective dihydroxylation of the olefin in amide seven was performed efficiently using chiral quinine ligand (DHQ) ${ }_{2}$ PHAL to yield enantioenriched dihydroxy propionamide derivative (+)-1 in moderate yields. In a similar way, the chiral quinidine ligand (DHQD) $)_{2}$ PHAL was used as stereoselectivity agent yielded the desired enantioenriched (-)-1. The enantioenriched products were used for further in vitro assay, and accordingly the percent enantiomeric excess (\% ee) was not determined. The structures of compounds were proven by spectral data $\left({ }^{1} \mathrm{H} N M R,{ }^{13} \mathrm{C}\right.$ NMR, and mass spectra).

Results: The phenol moiety at the C1 position of triclosan was chemically substituted with a methoxy group, in conjunction with an introduced stereocenter in a 2,3-dihydroxy-propionamide group at C2' position. Unmodified triclosan inhibited the $P$. falciparum cultures with an IC ${ }_{50}$ value of $27.2 \mu \mathrm{M}$. By contrast, the triclosan analogs, compounds $(+)-1$ and $(-)-1$, inhibited the $P$. falciparum cultures with $\mathrm{IC}_{50}$ values of 0.034 and $0.028 \mu \mathrm{M}$, respectively.

Conclusion: Collectively, our preliminary in vitro results suggest that these triclosan analogs have potent antimalarial activity and represent a promising new treatment strategy on further development.

Keywords: Triclosan, Synthetic analogs, Plasmodium falciparum, Antimalarial.

(c) 2020 The Authors. Published by Innovare Academic Sciences Pvt Ltd. This is an open access article under the CC BY license (http://creativecommons. org/licenses/by/4. 0/) DOI: http://dx.doi.org/10.22159/ijap.2020.v12s1.FF007

\section{INTRODUCTION}

To date, malaria remains one of the most devastating diseases of tropical and subtropical countries and is caused by the protozoan parasites of the Plasmodium genus. Worldwide, malaria causes over 500 million new cases each year, with approximately 3 billion people living under the threat of malaria. The disease results in as many as 2.7 million deaths annually, with children mostly affected. In addition, malaria has a striking correlation with social and economic disruption on a grand scale [1-5].

Chemoresistance is of increasing concern, primarily for Plasmodium falciparum, the parasite responsible for cerebral malaria, which is the most serious type of malaria infection. Indeed, this chemoresistance is believed to be a major factor in the worldwide upsurge of malaria [6]; therefore, there is an urgent need for new and potent antimalarial treatments [7].

The trichlorinated biphenyl ether triclosan [5-chloro-2-(2,4-dichlorophenoxy) phenol ether] (Fig.1) is an antimicrobial component sometimes added to consumer products such as toothpastes, mouthwashes, deodorant soaps, lotions, and children toys [8]. Nevertheless, FDA nowadays has a restriction on triclosan as the emerging resistance issues. Triclosan's effectiveness as an antimicrobial agent is believed to be due to its ability to inhibit the enzyme enoylacyl carrier protein reductase, which is involved in bacterial lipid biosynthesis [9-11]. In vitro studies confirm that triclosan is effective at killing P. falciparum and curing mice infected with the rodent malaria species Plasmodium berghei, as well as acute bacterial infection $[12,13]$. Appropriation as their potential efficacy against malaria parasites needs to be developed steadily to get the structure that is pharmacologically suitable for use in humans.

Continuing the work of earlier studies attempting to identify new and potent antimalarial treatments [14-20], in this study, we synthesized modified structures of triclosan and evaluated their antimalarial activities.

\section{EXPERIMENTAL}

Synthesis of compounds

General methods

All starting materials were obtained from Sigma-Aldrich, Wako Pure, or Tokyo Chemical Industries and used as supplied. Solvents for chemical synthesis were acquired from commercial sources and used without further purification unless otherwise stated. Flash column chromatography was performed using Merck silica gel 60, whereas reactions and chromatography fractions were performed using Merck thin-layer chromatography (TLC) plates $60 \mathrm{~F}_{254^{*}}$ Compounds were visualized by an ultraviolet lamp (254 and $360 \mathrm{~nm}$ ). Melting points $\left({ }^{\circ} \mathrm{C}\right)$ were determined with a Yanaco micro melting point apparatus and remained uncorrected. Specific rotation, $[\alpha]_{D}$, was measured on a Jasco Digital Polarimeter. Mass analysis was performed with an electrospray mass JEOL JMS-AX 700 spectrometer, and gas chromatography was coupled with a mass spectrometer of high-resolution. ${ }^{1} \mathrm{H}$ and ${ }^{13} \mathrm{C}$ NMR spectral analyses were performed on a JEOL JNM-ECP500 (500 MHz), with tetramethylsilane as the internal standard. Chemical shifts are reported in units of $(\delta) \mathrm{ppm}$. The following abbreviations were used 


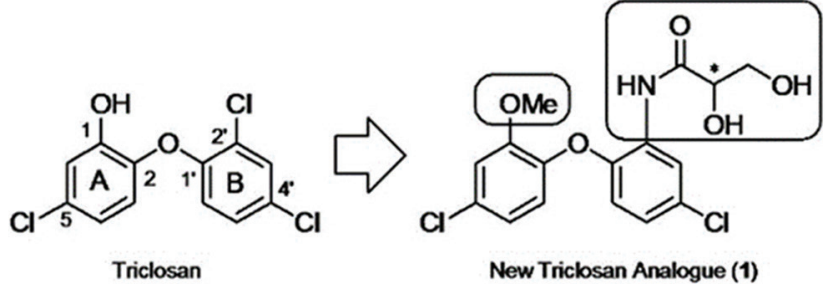

Fig. 1: Triclosan and the designed derivatives

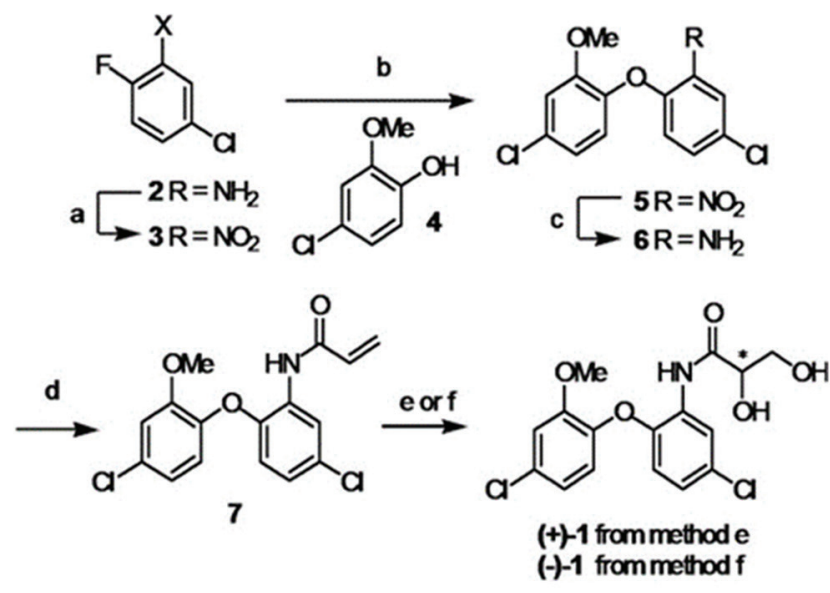

Fig. 2: Reagents and conditions: (a) $m$-CPBA, 1,2-dichloroethane, $84^{\circ} \mathrm{C}, 73 \%$; (b) $\mathrm{K}_{2} \mathrm{CO}_{3} / \mathrm{DMF}, 18$-crown-6, $60^{\circ} \mathrm{C}, 73 \%$; (c) Sn/Conc. $\mathrm{HCl}, \mathrm{EtOH}, 100^{\circ} \mathrm{C}, 62 \%$; (d) acryloyl chloride, $\mathrm{Et}_{3} \mathrm{~N} / \mathrm{THF}, \mathrm{N}_{2}(g), 0^{\circ} \mathrm{C}$, 76\%; (e) (DHQ) 2 PHAL, $\mathrm{K}_{3} \mathrm{Fe}(\mathrm{CN})_{6}, \mathrm{~K}_{2} \mathrm{CO}_{3}, \mathrm{NaHCO}_{3}, \mathrm{OsO}_{4}$, RT to $0^{\circ} \mathrm{C}$, 75\%; (f) (DHQD) 2 PHAL, $\mathrm{K}_{3} \mathrm{Fe}(\mathrm{CN})_{6}, \mathrm{~K}_{2} \mathrm{CO}_{3}, \mathrm{NaHCO}_{3}, \mathrm{OsO}_{4}, \mathrm{RT}$ to $\mathrm{O}^{\circ} \mathrm{C}$, $70 \%$

to explain the multiplicities: s, singlet; $d$, doublet; $t$, triplet; dd, double doublet; m, multiplet, and br, broad.

\section{4-Chloro-1-fluoro-2-nitro-benzene (3)}

A three-neck round-bottomed flask was charged with $m$-CPBA (3.16 g, $14.5 \mathrm{mmol}$ ) dissolved in 1,2-dichloroethane $(13 \mathrm{~mL})$. The mixture was refluxed until it reached the boiling point of the solvent $\left(84^{\circ} \mathrm{C}\right)$. To this mixture, a solution of 5-chloro-2-fluoro-phenylamine $2(0.4 \mathrm{~mL}$, $3.5 \mathrm{mmol}$ ) in 1,2-dichloroethane (3.5 mL) was added dropwise using an addition funnel. After $3 \mathrm{~h}$, the reaction mixture was cooled to room temperature (RT), diluted with $\mathrm{CHCl}_{3}$ and washed with a $5 \% \mathrm{NaOH}$ solution, water, and diluted $\mathrm{HCl}$ to remove excess and unreacted starting materials. The organic layer was then washed in a brine solution and dried over anhydrous $\mathrm{MgSO}_{4}$. The product 3 (yellow liquid) containing trace $m$-chloroquine acid was used for the further reaction without purification (425 mg, 73\%). TLC Rf 0.42 (hexane/EtOAc 20:1); ${ }^{1} \mathrm{H}$ NMR $\left(\mathrm{CDCl}_{3}, 500 \mathrm{MHz}\right) \delta: 8.00(\mathrm{dd}, J=2.7$ and $6.4 \mathrm{~Hz}, 1 \mathrm{H}), 7.55(\mathrm{dq}, J=8.9$ and $2.2 \mathrm{~Hz}, 1 \mathrm{H}), 7.22\left(\mathrm{dt}, J=9.6\right.$ and $4.0 \mathrm{~Hz}, 1 \mathrm{H}$ ). HRMS-EI ${ }^{+} \mathrm{m} / \mathrm{z}$ : Calcd for $\mathrm{C}_{6} \mathrm{H}_{3} \mathrm{ClFNO}_{2:} 174.9836[\mathrm{M}]^{+}$; found: 174.9829 .

\section{4-Chloro-1-(2'-methoxy-4'-chloro-phenoxy)-2-nitro-benzene (5)}

To a solution of compound $3(0.30 \mathrm{~g}, 1.72 \mathrm{mmol})$ and 4-chloro-2methoxy-phenol $4(0.2 \mathrm{~mL}, 1.65 \mathrm{mmol})$ in dimethylformamide (DMF) ( $3.5 \mathrm{~mL}$ ), anhydrous $\mathrm{K}_{2} \mathrm{CO}_{3} 0.5 \mathrm{~g}$ ) and a catalytic amount of 18-crown-6 were added and stirred in an oil bath at $60^{\circ} \mathrm{C}$ for $3 \mathrm{~h}$. After the reaction was complete, the reaction mixture was cooled to RT and diluted with toluene. The organic layer was then washed with a $10 \% \mathrm{NaOH}$ solution, water, and a brine solution and then dried over anhydrous $\mathrm{MgSO}_{4}$. The crude product was purified on silica using a 15-30\% toluene/hexane mixture to yield $376 \mathrm{mg}$ (73\%) of the compound 5 (yellow liquid). TLC Rf 0.31 (hexane/EtOAc 20:1); ${ }^{1} \mathrm{H}$ NMR $\left(\mathrm{CDCl}_{3}, 500 \mathrm{MHz}\right) \delta: 7.93$ (d, $J=3.1 \mathrm{~Hz}, 1 \mathrm{H}), 7.38(\mathrm{dd}, J=2.7$ and $8.9 \mathrm{~Hz}, 1 \mathrm{H}), 6.96-7.02(\mathrm{~m}, 3 \mathrm{H})$, $6.76(\mathrm{~d}, J=9.2 \mathrm{~Hz}, 1 \mathrm{H}), 3.76(\mathrm{~s}, 3 \mathrm{H}) ;{ }^{13} \mathrm{C} \mathrm{NMR}\left(\mathrm{CDCl}_{3}, 125 \mathrm{MHz}\right) \delta: 151.48$, $149.89,141.28,139.63,133.81,131.51,127.02,125.26,122.49,120.96$, 118.89, 113.56, 55.96. HRMS-ESI ${ }^{+} \mathrm{m} / \mathrm{z}$ : Calcd for $\mathrm{C}_{13} \mathrm{H}_{9} \mathrm{Cl}_{2} \mathrm{NO}_{4:} 335.9806$ $[\mathrm{M}+\mathrm{Na}]^{+}$; found: 335.9806 .

\section{5-Chloro-2'-(4'-chloro-2-methoxy-phenoxy)-phenylamine (6)}

Tin metal $(0.18 \mathrm{~g})$ and conc. $\mathrm{HCl}(0.5 \mathrm{~mL})$ were added to the solution of compound 5 ( $0.10 \mathrm{~g}, 0.33 \mathrm{mmol})$ in EtOH ( $2 \mathrm{~mL}$ ) in a $100 \mathrm{~mL}$ roundbottomed flask. The mixture solution was refluxed at $100^{\circ} \mathrm{C}$ for $3 \mathrm{~h}$ and then cooled to RT, to which a solution of $30 \% \mathrm{NaOH}$ was added until the white precipitate was dissolved. The solution was then extracted with ether, washed with water and brine solution, and dried over anhydrous $\mathrm{MgSO}_{4}$. The crude product was purified on a silica gel column using $40-70 \%$ toluene/hexane to yield $62 \%$ (58 mg) of compound 6 . Offwhite solid, m.p: $67^{\circ} \mathrm{C}$. TLC Rf 0.45 (hexane/EtOAc $4: 1$ ); ${ }^{1} \mathrm{H}$ NMR $\left(\mathrm{CDCl}_{3}, 500 \mathrm{MHz}\right) \delta: 6.96(\mathrm{~d}, J=2.4 \mathrm{~Hz}, 1 \mathrm{H}), 6.85(\mathrm{~d}, J=2.4 \mathrm{~Hz}, 1 \mathrm{H}), 6.84$ (d, $J=2.4 \mathrm{~Hz}, 1 \mathrm{H}), 6.78(\mathrm{~d}, J=8.6 \mathrm{~Hz}, 1 \mathrm{H}), 6.74(\mathrm{~d}, J=1.8 \mathrm{~Hz}, 1 \mathrm{H}), 6.60$ (d, $J=3.1 \mathrm{~Hz}, 1 \mathrm{H}), 3.94\left(\mathrm{~s}, 2 \mathrm{H}\left[\mathrm{NH}_{2}\right]\right), 3.76(\mathrm{~s}, 3 \mathrm{H}) ;{ }^{13} \mathrm{C} \mathrm{NMR}\left(\mathrm{CDCl}_{3}, 125\right.$ MHz) $\delta: 150.96,144.07,142.49,138.92,129.16 .81,129.11,120.73$, $119.59,118.94,118.04,115.76,113.15,56.12$. HRMS-EI $^{+} \mathrm{m} / \mathrm{z}$ : Calcd for $\mathrm{C}_{13} \mathrm{H}_{11} \mathrm{Cl}_{2} \mathrm{NO}_{2:} 283.0167[\mathrm{M}]^{+}$; found: 283.0164.

$N$-[5-Chloro-2-(4-chloro-2-methoxy-phenoxy)-phenyl]-acrylamide (7) To a solution of triethylamine $(0.03 \mathrm{~mL}, 0.42 \mathrm{mmol})$, dry THF (1.5 mL) under $\mathrm{N}_{2}$ was added to give the amine compound 6 (50 $\mathrm{mg}, 0.14 \mathrm{mmol}$ ) at $0^{\circ} \mathrm{C}$. After stirring for $15 \mathrm{~min}$, acryloyl chloride $(0.02 \mathrm{~mL}, 0.28 \mathrm{mmol})$ was introduced, and the mixture was allowed to warm to RT for $3 \mathrm{~h}$. The mixture was then diluted with EtOAc, $1 \mathrm{M} \mathrm{HCl}$, water, saturated $\mathrm{NaHCO}_{3}$, and a brine solution. The solution was then dried over anhydrous $\mathrm{MgSO}_{4}$, and the crude extract was purified by column chromatography on a silica gel using 10:1 hexane/EtOAc to obtain product 7 (45 mg, $76 \%$ ) as an off-white liquid. TLC Rf 0.37 (hexane/EtOAc 4:1); ${ }^{1} \mathrm{H}$ NMR $\left(\mathrm{CDCl}_{3}, 500 \mathrm{MHz}\right) \delta: 8.59(\mathrm{~s}, 1 \mathrm{H}[\mathrm{NH}]), 8.12(\mathrm{~s}, 1 \mathrm{H}), 6.94(\mathrm{~m}, 4 \mathrm{H}), 6.59(\mathrm{~d}$, $J=9.2 \mathrm{~Hz}, 1 \mathrm{H}), 6.44(\mathrm{t}, J=8.2 \mathrm{~Hz}, 1 \mathrm{H}), 6.30(\mathrm{dd}, J=16.8$ and $10.1 \mathrm{~Hz}, 1 \mathrm{H})$, $5.78(\mathrm{dd}, J=10.4$ and $1.2 \mathrm{~Hz}, 1 \mathrm{H}), 3.78(\mathrm{~s}, 3 \mathrm{H}) ;{ }^{13} \mathrm{C} \mathrm{NMR}\left(\mathrm{CDCl}_{3}, 125 \mathrm{MHz}\right)$ $\delta: 163.33,151.61,145.04,142.46,130.96,129.42,128.41,128.20$, $123.47,122.30,120.99,120.55,116.03,113.43,56.02$. A quaternary carbon atom that binds chlorine appeared as a single peak. HRMS-EI ${ }^{+}$ $m / z$ : Calcd for $\mathrm{C}_{16} \mathrm{H}_{13} \mathrm{Cl}_{2} \mathrm{NO}_{3:} 337.0272\left[\mathrm{M}^{+}\right.$; found: 337.0273 .

(Method e) enantioenriched from chiral ligand (DHQ) 2 PHAL ((+)-1) To a stirred solution of amide $7(0.20 \mathrm{~g}, 0.60 \mathrm{mmol})$ in $16 \mathrm{~m} t$-BuOH: $\mathrm{H}_{2} \mathrm{O}$ (1:1), $\mathrm{K}_{3} \mathrm{Fe}(\mathrm{CN})_{6}(1.17 \mathrm{~g}, 3.56 \mathrm{mmol})$ was added, along with anhydrous $\mathrm{K}_{2} \mathrm{CO}_{3}(0.5 \mathrm{~g}, 3.56 \mathrm{mmol}), \mathrm{NaHCO}_{3}(0.2 \mathrm{~g}, 3.56 \mathrm{mmol})$, and (DHQ) ${ }_{2} \mathrm{PHAL}$ $(0.14 \mathrm{~g}, 30 \mathrm{~mol} \%)$. The resulting mixture was stirred at RT for $10 \mathrm{~min}$, and the solution was then cooled to $0^{\circ} \mathrm{C}$. To this solution, we added $\mathrm{OsO}_{4}(40 \mathrm{~mol} \%)$ and continued at $0^{\circ} \mathrm{C}$ for $4 \mathrm{~h}$. The reaction was quenched by the addition of water $(15 \mathrm{~mL})$ and $\mathrm{Na}_{2} \mathrm{SO}_{3}(0.5 \mathrm{~g}, 4.0 \mathrm{mmol})$. The resulting mixture was extracted using $\mathrm{CH}_{2} \mathrm{Cl}_{2}$. The combined $\mathrm{CH}_{2} \mathrm{Cl}_{2}$ layers were then dried over anhydrous $\mathrm{MgSO}_{4}$, filtered, and concentrated under reduced pressure. The crude residue was then purified by column chromatography on silica (gradient elution 99:1-98:2, $\mathrm{CHCl}_{3}: \mathrm{CH}_{3} \mathrm{OH}$ ) to give an enantiomer mixture of products (+)-1 (165 mg, 75\%) as a white solid, m.p.: $162^{\circ} \mathrm{C},[\alpha]_{\mathrm{D}}{ }^{27}(+) 4.0^{*},(c=0.40)$. TLC Rf $0.3\left(\mathrm{CHCl}_{3} / \mathrm{CH}_{3} \mathrm{OH}\right.$ 96:4); ${ }^{1} \mathrm{H}$ NMR ( $\left.\mathrm{CDCl}_{3}, 500 \mathrm{MHz}\right) \delta: 8.42(\mathrm{~d}, J=2.4 \mathrm{~Hz}, 1 \mathrm{H}), 7.16(\mathrm{~d}, J=1.8 \mathrm{~Hz}$, $1 \mathrm{H}), 7.09$ (d, J=8.6 Hz, 1H), 6.96-7.00 (m, 2H), 6.62 (d, J=8.6 Hz, 1H), 4.21 $(\mathrm{t}, J=4.0 \mathrm{~Hz}, 1 \mathrm{H}), 3.83(\mathrm{t}, J=2.4 \mathrm{~Hz}, 2 \mathrm{H}), 3.77(\mathrm{~s}, 3 \mathrm{H}) ;{ }^{13} \mathrm{C}$ NMR $\left(\mathrm{CDCl}_{3}, 125\right.$ MHz) $\delta: 173.16,153.57,147.43,143.89,132.34,129.94,128.75,124.86$, $124.00,121.98,121.19,117.17,114.83,74.63,65.20,56.70$. HRMS-EI $^{+}$ $\mathrm{m} / \mathrm{z}$ : Calcd for $\mathrm{C}_{16} \mathrm{H}_{15} \mathrm{Cl}_{2} \mathrm{NO}_{5} 371.0327[\mathrm{M}]^{+}$; found: 371.0322 .

(Method $f$ ) enantioenriched from chiral ligand (DHQD) ${ }_{2}$ PHAL ((-)-1) To a stirred solution of amide $7(0.20 \mathrm{~g}, 0.60 \mathrm{mmol})$ in $16 \mathrm{~mL} t$-BuOH: $\mathrm{H}_{2} \mathrm{O}$ (1:1), $\mathrm{K}_{3} \mathrm{Fe}(\mathrm{CN})_{6}(1.17 \mathrm{~g}, 3.56 \mathrm{mmol})$ was added, along with anhydrous $\mathrm{K}_{2} \mathrm{CO}_{3}(0.5 \mathrm{~g}, 3.56 \mathrm{mmol}), \mathrm{NaHCO}_{3}(0.2 \mathrm{~g}, 3.56 \mathrm{mmol})$, and (DHQ) $)_{2} \mathrm{PHAL}$ $(0.14 \mathrm{~g}, 30 \mathrm{~mol} \%)$. The resulting mixture was stirred at RT for $10 \mathrm{~min}$, and this solution was then cooled to $0^{\circ} \mathrm{C}$. To this solution, we added $\mathrm{OsO}_{4}(40 \mathrm{~mol} \%)$ and continued stirring at $0^{\circ} \mathrm{C}$ for $4 \mathrm{~h}$. The reaction was 


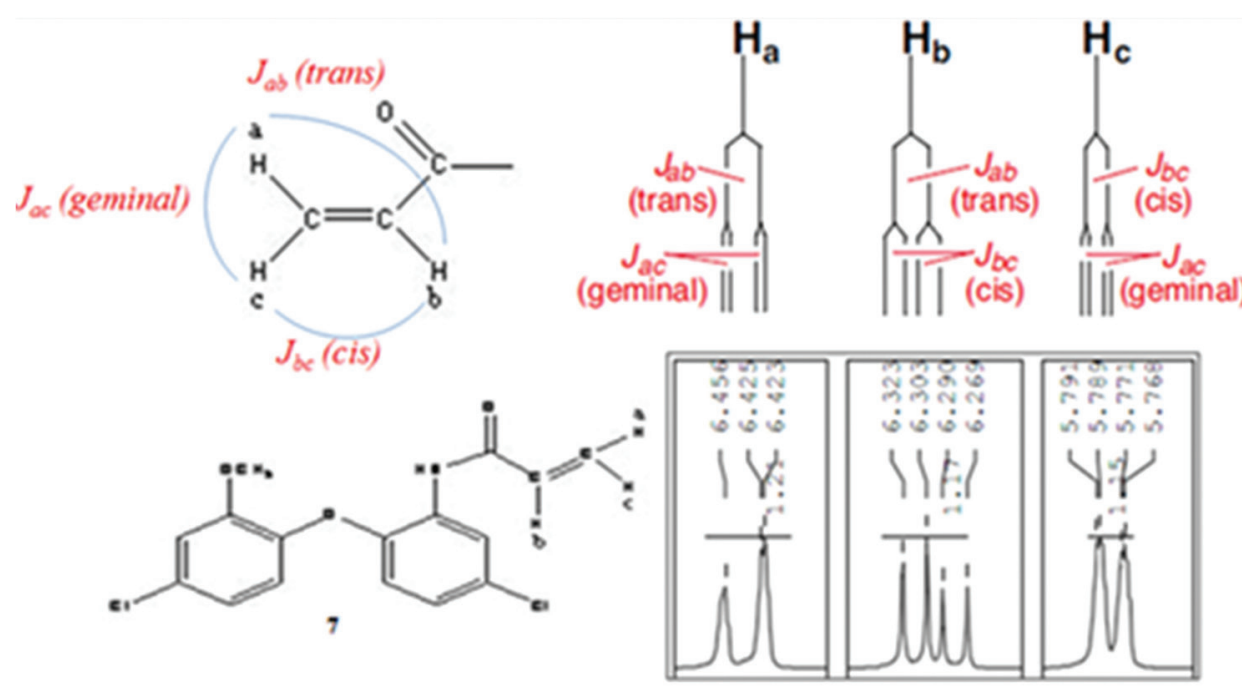

Fig. 3: The splitting pattern of hydrogen atoms on the vinyl group of amide 7

quenched by the addition of water $(15 \mathrm{~mL})$ and $\mathrm{Na}_{2} \mathrm{SO}_{3}(0.5 \mathrm{~g}, 4.0 \mathrm{mmol})$. The resulting mixture was extracted using $\mathrm{CH}_{2} \mathrm{Cl}_{2}$. The combined $\mathrm{CH}_{2} \mathrm{Cl}_{2}$ layers were dried over anhydrous $\mathrm{MgSO}_{4}$, filtered, and concentrated under reduced pressure. The crude residue was then purified by column chromatography on silica (gradient elution 100:0-98:2, $\mathrm{CHCl}_{3}: \mathrm{CH}_{3} \mathrm{OH}$ ) to give an enantiomer mixture of products (-)-1 (154 mg, 70\%) as a white solid, m.p.: $158^{\circ} \mathrm{C},[\alpha]_{\mathrm{D}}^{27}(-) 3.2^{*}$, (c=0.37). TLC Rf $0.32\left(\mathrm{CHCl}_{3} / \mathrm{CH}_{3} \mathrm{OH}\right.$ 96:4); ${ }^{1} \mathrm{H}$ NMR $\left(\mathrm{CDCl}_{3}, 500 \mathrm{MHz}\right) \delta: 8.42(\mathrm{~d}, J=2.4 \mathrm{~Hz}, 1 \mathrm{H}), 7.16(\mathrm{~d}, J=2.4 \mathrm{~Hz}$, $1 \mathrm{H}), 7.09(\mathrm{~d}, J=8.6 \mathrm{~Hz}, 1 \mathrm{H}), 6.95-7.00(\mathrm{~m}, 2 \mathrm{H}), 6.62(\mathrm{~d}, J=8.6 \mathrm{~Hz}, 1 \mathrm{H}), 4.22$ $(\mathrm{t}, J=4.3 \mathrm{~Hz}, 1 \mathrm{H}), 3.83(\mathrm{t}, J=2.4 \mathrm{~Hz}, 2 \mathrm{H}), 3.77(\mathrm{~s}, 3 \mathrm{H}) ;{ }^{13} \mathrm{C} \mathrm{NMR}\left(\mathrm{CDCl}_{3}, 125\right.$ MHz) $\delta: 173.16,153.56,147.41,143.89,132.34,129.94,128.74,124.86$, 123.99, 121.97, 121.19, 117.17, 114.82, 74.62, 65.19, 56.69. HRMS-EI ${ }^{+}$ $\mathrm{m} / \mathrm{z}$ : Calcd for $\mathrm{C}_{16} \mathrm{H}_{15} \mathrm{Cl}_{2} \mathrm{NO}_{5} 371.0326$ [M]'; found: 371.0322 .

\section{Determination of the antimalarial activity}

The antimalarial activity of the synthesized molecules was evaluated against P. falciparum strain 3D7 (Eijkman Institute for Molecular Biology, Indonesia) using sensitive chloroquine and the procedure described by Budimulya [21]. P. falciparum 3D7 in human red blood cells (RBCs) (3\% initial parasite density, and $4 \%$ hematocrit) was cultured with the test compound (added as $150 \mu \mathrm{L}$ dimethyl sulfoxide solution) in $1350 \mu \mathrm{L}$ of the medium (RPMI-1640, $25 \mu \mathrm{g} / \mathrm{mL}$ gentamycin, $50 \mu \mathrm{g} / \mathrm{mL}$ hypoxanthine, $25 \mathrm{mM}$ Hepes buffer, $25 \mathrm{mM} \mathrm{NaHCO}_{3}$, and $10 \%$ human serum) using a 96 -well microtiter plate at $37^{\circ} \mathrm{C}$. Tests were carried out simultaneously for three molecules in duplicate. A sealed incubation chamber continuously gassed with a mixture of $2 \% \mathrm{O}_{2}, 8 \% \mathrm{CO}_{2}$, and $90 \% \mathrm{~N}_{2}$ was used. Increases in the proportion of infected RBCs were assessed at the end of the $48 \mathrm{~h}$ incubation period in control samples and at various concentrations of each drug using Giemsa stained slides. Control samples contained P. falciparum 3D7 without any test compounds. The growth of the parasite was monitored by performing a blood smear fixed with $\mathrm{MeOH}$ and stained with a Giemsa stain. The antimalarial activity of each compound was expressed as an $\mathrm{IC}_{50}$ value, defined as the concentration of the compound causing 50\% inhibition of parasite growth relative to the untreated control.

\section{RESULTS AND DISCUSSION}

Compound 6 was prepared by three chemical reactions in accordance with a previously reported procedure [18] (Fig. 2). Primary amine 2 in a commercially available form was oxidized with $m$-CPBA to form the corresponding nitrobenzene 3. Diphenyl ether derivative 5 was obtained by the coupling of the methoxy phenol 4 and nitrobenzene 3 in the presence of $\mathrm{K}_{2} \mathrm{CO}_{3}$ and 18-crown-6 in DMF. The nitro group in 5 was easily reduced with $\mathrm{Sn} / \mathrm{HCl}$ by reflux in ethanol to afford the known compound 6.
In dry THF, the amidation of 6 with acryloyl chloride afforded the desired amide 7. The amidation of 6 with acrylic acids and carbodiimide reagents was also attempted but was unsuccessful to give the desired amide 7. Diamagnetic anisotropy, which is commonly associated with asymmetric monosubstituted alkenes, appeared on the terminal olefin group of compound 7. Each of the three hydrogen atoms contributed inequivalently to form an exceptional splitting pattern (Fig. 3). The resulting peak of each hydrogen atom was expressed in terms of a chemical shift $6.44 \mathrm{ppm}(\mathrm{t}, J=8.2 \mathrm{~Hz}), 6.30 \mathrm{ppm}(\mathrm{dd}, J=16.8 \mathrm{~Hz}$ and $10.1 \mathrm{~Hz}$ ), and $5.78 \mathrm{ppm}(\mathrm{dd}, J=10.4 \mathrm{~Hz}$ and $1.2 \mathrm{~Hz}$ ).

Enantioselective dihydroxylation of the olefin in amide 7 was performed efficiently using the Sharpless et al. asymmetric dihydroxylation reaction [22] and the chiral quinine ligand (DHQ) ${ }_{2}$ PHAL, to yield enantioenriched dihydroxy propionamide derivative $(+)-1$ in moderate yields, attributed to a specific rotation, $[\alpha](+) 4.0\left(c=0.40\right.$, in $\left.\mathrm{CH}_{3} \mathrm{OH}\right)$. Similarly, when the catalyst was changed to the quinidine derivative (DHQD) $)_{2}$ PHAL, the opposite selectivity was observed, and it yielded the desired enantioenriched $(-)-1$ with a specific rotation, $[\alpha](-) 3.2$ $\left(c=0.37\right.$, in $\left.\mathrm{CH}_{3} \mathrm{OH}\right)$. As reported by Sharpless et al. and associates in 2001, these chiral ligands have proven to be superior to others for the dihydroxylation of olefins with aliphatic substituents [22]. The enantioenriched products were used for further in vitro assays, with the percent of enantiomeric excess (\% ee) not determined. The structures of compounds were proven by spectral data $\left({ }^{1} \mathrm{H}\right.$ NMR, ${ }^{13} \mathrm{C}$ NMR, and mass spectra).

All inhibitors were tested for their inhibition of growth of the blood stages of the parasite P. falciparum 3D7 culture for $48 \mathrm{~h}$ in human blood. The activities of the test compounds compared with those of reference drugs are presented in Table 1. From the biological test results generated, analog (-)-1 appears to possess activity nearly as active as analog (+)-1 at lower micromolar concentrations. Qualitatively, this is understood by the fact that the specific configurations $(R$, rectus and $S$, sinister) of the enantiomers of these analogs are both active. This is likely because each of these cinchona ligands produced high enantiomer excess of a certain configuration [23].

Our results indicate that both of the enantioenriched analogs (+)-1 and (-)-1 of the 2'-chloro- and phenol-modified series exhibited better antimalarial activity profiles than the unsubstituted triclosan. Hence, triclosan inhibited P. falciparum cultures with an $\mathrm{IC}_{50}$ of $27.2 \mu \mathrm{M}$, whereas the analogs (+)-1 and (-)-1 inhibited the cultures with $\mathrm{IC}_{50}$ values of 0.034 and $0.028 \mu \mathrm{M}$, respectively. In comparison, the $\mathrm{IC}_{50}$ value for chloroquine, a well-established drug for the treatment of malaria, is $0.0003 \mu \mathrm{M}$. Therefore, given our activity results, it will be necessary to 
Table 1: Experimental IC ${ }_{50}$ values of the inhibitors against Plasmodium falciparum strain 3D7

\begin{tabular}{ll}
\hline Compound & Experimental IC $_{\mathbf{5 0}}(\boldsymbol{\mu} \mathbf{M})^{\mathrm{a}}$ \\
\hline$(+)-1,[\alpha]_{\mathrm{D}}^{27}(+) 4.0^{*},(c=0.40)$ & 0.034 \\
$(-)-1,[\alpha]_{\mathrm{D}}^{27}(-) 3.2^{*},(c=0.37)$ & 0.028 \\
Triclosan & 27.2 \\
Chloroquine & 0.0003 \\
\hline
\end{tabular}

*The specific rotations determined in $\mathrm{CH}_{3} \mathrm{OH},{ }^{a} \mathrm{IC}_{50}$ taken from the Giemsa

stained slide method (MIC method)

add more chemical attributes to these molecules to make them active at the nanomolar level.

\section{CONCLUSION}

We have synthesized novel triclosan analogs that appear to have potent antiplasmodial activity. The design of these new analogs was initiated with the introduction of chirality, and the analogs were synthesized in five steps to obtain a moderate yield. These favorable preliminary in vitro results demonstrating the potency of the synthesized compounds, (+)-1 and $(-)-1$, indicate that these compounds, particularly with additional modification, may prove to be promising antimalarial leads based on the concept of drug enantioselectivity. Future efforts will seek to define the mode of action of these potent antimalarials while further optimizing their activity with a wider range of substituent groups that may offer improved antimalarial activity.

\section{ACKNOWLEDGMENTS}

This work was partially supported by the International Research Collaboration Program of the Nara Institute of Science and Technology (NAIST Global Initiative Program).

\section{CONFLICTS OF INTEREST}

The authors declare that there are no conflicts of interest.

\section{REFERENCES}

1. World Health Organization. Global Report on Antimalarial, Drug Efficacy and Drug Resistance: 2000-2010. Geneva: World Health Organization; 2010. p. 18.

2. Stratton L, O'Neill MS, Kruk ME, Bell ML. The persistent problem of malaria: Addressing the fundamental causes of a global killer. Soc Sci Med 2008;67:854-62.

3. Snow RW, Guerra CA, Noor AM, Myint HY, Hay SI. The global distribution of clinical episodes of Plasmodium falciparum malaria. Nature 2005;434:214-7.

4. Breman JG. The ears of the hippopotamus: Manifestations, determinants, and estimates of the malaria burden. Am J Trop Med Hyg 2001;64:1-1.
5. Sachs J, Malaney P. The economic and social burden of malaria. Nature 2002;415:680-5.

6. Clark IA, Cowden WB. The pathophysiology of falciparum malaria. Pharmacol Ther 2003;99:221-60.

7. Ridley RG. Medical need, scientific opportunity and the drive for antimalarial drugs. Nature 2002;415:686-93.

8. Jones RD, Jampani HB, Newman JL, Lee AS. Triclosan: A review of effectiveness and safety in health care settings. Am J Infect Control 2000;28:184-96

9. McMurry LM, Oethinger M, Levy SB. Triclosan targets lipid synthesis. Nature 1998;394:531-2.

10. Levy CW, RoujeinikovaA, Sedelnikova S, Baker PJ, StuitjeAR, Slabas AR, et al. Molecular basis of triclosan activity. Nature 1999;398:383-4.

11. Heath RJ, Rock CO. A triclosan-resistant bacterial enzyme. Nature 2000;406:145-6.

12. Surolia N, Surolia A. Triclosan offers protection against blood stages of malaria by inhibiting enoyl-ACP reductase of Plasmodium falciparum. Nat Med 2001;7:167-73.

13. Sharma S, Ramya TN, Surolia A, Surolia N. Triclosan as a systemic antibacterial agent in a mouse model of acute bacterial challenge. Antimicrob Agents Chemother 2003;47:3859-66.

14. Chhibber M, Kumar G, Parasuraman P, Ramya TN, Surolia N, Surolia A. Novel diphenyl ethers: Design, docking studies, synthesis and inhibition of enoyl ACP reductase of Plasmodium falciparum and Escherichia coli. Bioorg Med Chem 2006;14:8086-98.

15. Mishra S, Karmodiya K, Parasuraman P, Surolia A, Surolia N. Design, synthesis, and application of novel triclosan prodrugs as potential antimalarial and antibacterial agents. Bioorg Med Chem 2008;16:5536-46.

16. Perozzo R, Kuo M, Sidhu Ab, Valiyaveettil JT, Bittman R, Jacobs WR Jr., et al. Structural elucidation of the specificity of the antibacterial agent triclosan for malarial enoyl acyl carrier protein reductase. J Biol Chem 2002;277:13106-14.

17. Freundlich JS, Yu M, Lucumi E, Kuo M, Tsai HC, Valderramos JC, et al. Synthesis and biological activity of diaryl ether inhibitors of malarial enoyl acyl carrier protein reductase. Part 2: 2'-substituted triclosan derivatives. Bioorg Med Chem Lett 2006;16:2163-9.

18. Kapoor N, Banerjee T, Babu P, Maity K, Surolia N, Surolia A. Design, development, synthesis, and docking analysis of 2'-substituted triclosan analogs as inhibitors for Plasmodium falciparum enoyl-ACP reductase. IUBMB Life 2009;61:1083-91.

19. Rifai EA, Hayun H, Yanuar A. In silico screening of antimalarial from Indonesian medicinal plants database to plasmepsin target. Asian J Pharm Clin Res 2017;10:130-3.

20. Pamudi BF, Azizahwati A, Yanuar A. In-silico screening against antimalarial target Plasmodium falciparum enoyl-acyl carrier protein reductase. Asian J Pharm Clin Res 2017;10:127-9.

21. Budimulja AS, Syafruddin, Tapchaisri P, Wilairat P, Marzuki S. The sensitivity of Plasmodium protein synthesis to prokaryotic ribosomal inhibitors. Mol Biochem Parasitol 1997;84:137-41

22. Sharpless KB, Amberg W, Bennani YL, Crispino GL, Hartung J, Jeong K, et al. The osmium catalyzed asymmetric dihydroxylation: A new ligand class and a process improvement. J Org Chem 1992;57:2768-71.

23. Corey EJ, Noe MC. A critical analysis of the mechanistic basis of enantioselectivity in the bis-Cinchona alkaloid catalyzed dihydroxylation of olefins. J Am Chem Soc 1996;118:11038-35. 